\title{
ANALYSIS OF EFFECTIVENESS AND CONTRIBUTION OF ADVERTISEMENT TAX COLLECTION ON ORIGINAL REGIONAL INCOME
}

\author{
Ayi Astuti \\ Langlangbuana University, Indonesia \\ ayivhuvhu@gmail.com
}

\begin{abstract}
Advertisement tax is one of the potential regional revenues and can be collected efficiently, effectively and economically. Efforts to increase PAD can be done by increasing the effectiveness of local tax revenue from PAD sources especially advertisement tax. This research of advertisement tax collection on PAD in Bandung City and to determine the contribution of the realization of advertisement tax revenue in an effort to increase the original income of the city of Bandung in 2013 and 2017. This research is a descriptive verification study with a quantitative approach. The data used are secondary data by type and time series during the period of 2013 to 2017. Data analysis was performed through correlation coefficients, simple linear regression analysis, coefficient of determination analysis and hypothesis testing ( $t$ test). Correlation coefficient analysis results show that the analysis of the effectiveness and contribution of advertisement tax has a significant effect on the Original Local Revenue at the Bandung City Tax Service.
\end{abstract}

Keywords: PAD, Advertisement Tax, Contribution

\section{INTRODUCTION}

Taxes are the most central government revenue, this is because the tax contribution to the government budget is very large (Diana Sari, 2013). Taxes are the largest income compared to other regional income, this is because there are many types of taxes and all activities in the company can be taxed according to the provisions (Khasanah, 2014). Taxes are obligations that are imposed on and collected from Indonesian citizens (Diana Sari, 2013). Local taxes are used for regional household costs and activity costs to carry out government duties (Mardiasmo, 2013). Sources of regional revenue can come from local taxes which can be developed according to regional conditions. The results can be used to support the smooth running of development and governance. Local governments have the authority to regulate and manage their regions, and have achievement targets to increase regional income to be more advanced (Khasanah, 2014). Management of resources owned by the potential and interests of the region itself for empowerment in decision making in regional autonomy. To be able to carry out optimal regional autonomy, sufficient funds are needed. According to the government regulation concerning regional pearutan referred to as PAD itself, it states that regional or government revenues have added certain budgets for regional activities. PAD is income received and originating from tax collection within its territory according to the prevailing laws and regulations. According to Halim (2010: 110 ), the sources of PAD consist of local taxes, regional levies and the results of companies owned by the regions, the results of the management of separated regional assets and other legal PAD. Thus, it will increase the income that will be obtained from various independent activities (Febriansyah, 2015).

Regional tax as PAD is measured by the amount of contribution from the regional revenue budget where one of the ways is by optimizing regional taxes to taxpayers which are compelling in accordance with the applicable laws by obtaining indirect rewards that are used 
for regional needs and the prosperity of the people. Not all local taxes apply in all regions, because they are determined according to the potential in the area (Khasanah, 2014). One of the objects of local taxes that are collected and can be relied on to increase the revenue of PAD is the advertisement tax. Advertisement tax is a tax that has many kinds of purposes for commercial purposes by introducing and promoting goods or services or entities that can be in the form of reading, audio or other things that can be enjoyed by the public (Siahaan, 2010). The city of Bandung is one of the tourist cities in Indonesia which is frequently visited by domestic or international tourists, the large number of tourists who come makes Bandung often used as a strategic location or place to introduce or publish a product. Watini (2010) states that such conditions require companies to have a strategy so that they can continue to grow to maintain their existence, corporate strategies in introducing and marketing their products so that the company's sales (revenue) increase and the company's market share can be expanded through advertising media (billboards). The city of Bandung has great potential to generate revenue from billboard taxes to increase PAD. The problem is that in Bandung, there are still many illegal billboards that do not pay annual taxes. There are far more illegal billboards than those who pay taxes, so the potential tax from advertisement taxes is very large if all collectable (Fidel, 2010). At least 5,379 scattered on the streets of Bandung City do not have licenses for their reclamation units (Aristanti, 2013). In addition, the target resulting from tax revenue is known to be lower than the actual potential. Thus, the potential leakage of tax revenue is wide open, one of which is the advertisement tax that is not applied and collected, which occurs as a result of inaccurate data on the size / type of advertisements installed in the field (Lukman, 2015). The government as the organizer in increasing and stipulating development in the regions evenly makes efforts with the empowerment of government apparatus in the regions whose implementation and security are also necessary for effective and efficient supervision so that national development runs well. The utilization of government officials is very important in the management of PAD to finance regional development. Currently, billboards in Bandung are out of control in that the distribution of overlapping locations can also disturb the comfort of the community. As a result of these conditions, the problem of billboards is widely used by parties who are looking for profit regardless of the procedures or rules according to the regional regulations (Almanda, 2013) Referring to the description above, the researcher took the title regarding the billboard tax collection, namely "Analysis of the Effectiveness and Contribution of Advertising Tax Collection on Local Revenue at the Bandung City Tax Service Office". Original Regional Revenue, Based on Law Number 32 of 2004 concerning regional governance and Law Number 33 of 2004: PAD is revenue obtained by regions which is collected based on regional regulations in accordance with statutory regulations. According to Rustian Kamaludin (2012: 47): Regional original income is regional income that comes from local taxes, local retribution, the results of separated regional wealth management, and other legitimate local revenue, which aims to provide flexibility to the explore funding for the implementation of regional autonomy as a manifestation of the principle of decentralization. Original regional income is one of the sources that growth must always be spurred, because it is an important indicator to meet the level of government independence in the financial sector, the higher the function of PAD on the regional expenditure budget in the government and regional budget plans. Local taxes are mandatory payments imposed based on laws that cannot be avoided for those who are obliged and those who do not want to pay taxes can be forced (Siahaan, 2010: 7). 
In addition, the imposition of taxes based on law guarantees justice and legal certainty for taxpayers so that the government cannot arbitrarily determine the amount of tax to be paid. Regional taxes are determined by the regional government, whose collection authority is exercised by the regional government and the proceeds are used to finance regional government expenditures in implementing governance and development in the regions. Based on $\mathrm{RI}$ Law No. 28 of 2009 Article 2 paragraph (44) explains "the tax subject is an individual or entity that is subject to tax". Article 2 paragraph (45) explains "Taxpayers are individuals or entities, including taxpayers, tax cutters and tax collectors who have tax rights and obligations in accordance with the provisions of laws and regulations". Determination of tax subjects and taxpayers on a type of regional tax is clearly determined in the regional regulations governing the relevant regional taxes (Siahaan, 2010: 57). The type of regional tax is determined in two regions, namely the Level I Region (Province) and the Level II Region (Municipality / Regency). Level I and Level II regions may not collect one or several types of tax that have been determined, if the regional tax potential is deemed inadequate.

Advertisement Tax, according to the Law of the Republic of Indonesia Number 28 of 2009 Article 1 number 26 and 27: Advertisement Tax is a tax on the implementation of advertisements. Whereas what is meant by advertisements is objects, tools, actions, or media whose forms and patterns are designed for commercial purposes to introduce, recommend, promote, or to attract general attention to goods, services, people, or bodies, which can be seen, read, heard. , felt, and / or enjoyed by the public. Meanwhile, according to Bandung City Regional Regulation No. 02 of 2010, Advertising Tax is as follows: "Advertisement Tax is a tax imposed on all advertisement operations by an individual or entity". The imposition of advertisement tax does not absolutely exist in all districts or cities in Indonesia. This is related to the authority given to district or city governments to impose or not impose a type of district / city tax. In order to be levied in a regency or city, the local government must first issue a Regional Regulation on Advertising Tax which will become the operational legal basis in the technical implementation of the imposition and collection of Advertising Tax in the regency or city concerned (Siahaan, 2010).

\section{Research Place}

\section{METHODS}

The research was conducted at the Bandung City Tax Service Office. Based on the object of this research, it will be analyzed how to analyze the effectiveness and contribution of billboard tax collection to local revenue at the Bandung city tax service office.

\section{Research methods}

The research method used in this research is descriptive and verification. According to Sugiyono (2015: 53) descriptive research is research conducted to determine the existence of independent variables, either only on one or more variables without making comparisons or connecting with other variables (independent variables are independent variables, not independent variables because if independent is always paired with the dependent variable). Sample The type of sampling in this study uses non-probability sampling techniques, according to Sugiyono (2015: 116) this technique is a sampling technique that does not provide the same opportunity or opportunity for each element or member of the population to be selected as a sample. The sample in this study is data on the realization of local revenue from the city of Bandung 2009 to 2013.

\section{RESULTS AND DISCUSSION Normality test \\ The normality test is an important requirement in testing the meaning of the}


regression coefficient. If the model is not normally distributed, the conclusion of the $t$ test is still in doubt because the t test statistic in the regression analysis is derived from the normal distribution. The results of the normality test can be seen in the table below:

Table 1. Normality test

One-Sample Kolmogorov-Smirnov Test

\begin{tabular}{|c|c|c|}
\hline & $\begin{array}{l}\text { Reception } \\
\text { Restaurant tax }\end{array}$ & $\begin{array}{l}\text { Original Income } \\
\text { Area }\end{array}$ \\
\hline $\mathrm{N}$ & 5 & 5 \\
\hline Mean & 88327526759.00 & 653715835309.40 \\
\hline 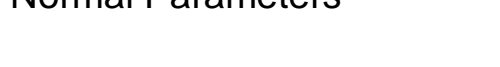 & 20839050456.74 & 380387973274511 \\
\hline Std. Deviation & 4 & \\
\hline Absolute & 0.161 & 0.222 \\
\hline Most Extreme Differences & & \\
\hline Positive & 0.161 & 0.222 \\
\hline Negative & -0.143 & -0.167 \\
\hline Kolmogorov-Smirnov Z & 0.359 & 0.497 \\
\hline Asymp. Sig. (2-tailed) & 1000 & 0.966 \\
\hline
\end{tabular}

A model is said to be normal if the normality test results are above 0.05 . The test results above show that the test results are good for the acceptance of the advertisement tax collection as variable $X$ of 1,000 and Regional Original Income as variable $Y$ of 0.966 can be said to be normal because the two data models have a value above the minimum limit as the data model is said to be normal, namely 0,05 .

Model Summary ${ }^{b}$

\begin{tabular}{|c|c|c|c|c|c|}
\hline Model & $\mathrm{R}$ & $\begin{array}{l}\text { R. } \\
\text { Square }\end{array}$ & $\begin{array}{l}\text { Adjusted } \\
\text { R } \\
\text { Square }\end{array}$ & $\begin{array}{l}\text { Std. Error of the } \\
\text { Estimate }\end{array}$ & $\begin{array}{l}\text { Durbin- } \\
\text { Watson }\end{array}$ \\
\hline 1 & $.989^{a}$ & 0.977 & 0.97 & 66228459045.603 & 3.304 \\
\hline
\end{tabular}

Predictors: (Constant), Advertising Tax Receipts

Dependent Variant: Original Income Area

Source: SPSS Version 20.0

The autocorrelation test results prove the Durbin-Watson autocorrelation test results show the number 3.304. The results are in accordance with the main requirements of this test, namely a model can be said to be good if the

\section{Autocorrelation Test}

The autocorrelation test is used to determine whether or not there is a deviation from the classic autocorrelation assumption, namely the correlation that occurs between the residuals in one observation and another in the regression model. In this study the test method used is the Durbin-Watson test with the following output results:

\section{Table 2. Autocorrelation Test}


Simple linear regression analysis is one of the tools used to determine the influence of the independent variable $(X)$ on the variable $(Y)$. the output results of these calculations are as follows:

Table 3. Regression Analysis

Coeficients $^{a}$

\begin{tabular}{lllll}
\hline Model & $\begin{array}{l}\text { Unstandardized } \\
\text { Coefficients } \\
\text { B }\end{array}$ & $\begin{array}{l}\text { Standardized } \\
\text { Coefficients } \\
\text { Std. error }\end{array}$ & Beta & Sig \\
\hline $\begin{array}{c}\text { (Constant) } \\
\begin{array}{c}\text { Income tax } \\
\text { Tax }\end{array}\end{array}$ & -9.40147461596 .289 & 1434475974 & -6554 & 0.007 \\
$\begin{array}{c}\text { Restaurant } \\
\text { Dependent Variabel: Original Income Area } \\
\text { Source: SPSS Version 20.0 }\end{array}$ & 11.356 & 0.001 \\
\hline
\end{tabular}

In Table 3, the probability value of the effect of restaurant tax revenue on local revenue is 0.05 . This figure shows that the regression model can and is appropriate to be used to predict Bandung City's Regional Original Income. From the calculation of the results of SPSS version 20.0 , it can be seen that the constant value is negative at -940 while the acceptance is positive at 18.045 . This means that there is a unidirectional relationship, which means that if the revenue $n$ increases by 1 unit, the original regional revenue will also increase by 18.045.

\section{Correlation Coefficient Analysis}

To ensure the strength or weakness of the relationship between income and operating profit, the author uses calculations using SPSS version 20.0, which can be seen in the table below:

Table 4. Coefficient Analysis Correlations

\begin{tabular}{|c|c|c|c|}
\hline & & $\begin{array}{l}\text { Pendapatan } \\
\text { Asli } \\
\text { Daerah }\end{array}$ & $\begin{array}{l}\text { Penerimaan Pajak } \\
\text { Restoran }\end{array}$ \\
\hline $\begin{array}{l}\text { Pearson } \\
\text { Correlation }\end{array}$ & Pendapatan Asli Daerah & 1.000 & 0.989 \\
\hline \multirow{3}{*}{ Sig. $\quad(1-$} & Penerimaan Pajak Restoran & 0.989 & 1 \\
\hline & Pendapatan Asli Daerah & . & .001 \\
\hline & Penerimaan Pajak Restoran & .001 & \\
\hline \multirow{2}{*}{$\mathrm{N}$} & Pendapatan Asli Daerah & 5 & 5 \\
\hline & Penerimaan Pajak Restoran & 5 & 5 \\
\hline
\end{tabular}


The correlation value for the effect of advertisement tax revenue on Regional Original Income amounted to 0.989 , which means that the variable relationship between advertisement tax revenue and Regional Original Income is very strong. Positive correlation shows that the relationship between billboard tax collection and Regional Original Income is unidirectional, meaning that if the increase in variable $X$ (billboard tax collection) will cause the dependent variable $Y$ (Regional
Original Income) to also increase or vice versa if the advertisement tax collection decreases, Regional Original Income will also follow. down.

\section{Analysis of the coefficient of determination}

To find out how much restaurant tax has an effect on local revenue in Bandung, the coefficient of determination is used. can be seen in the results of the determination coefficient test as follows:

Table 5. Analysis of the coefficient of determination

\begin{tabular}{lllll}
\hline Model & $R$ & $\begin{array}{l}\text { R. } \\
\text { Square }\end{array}$ & $\begin{array}{l}\text { Adjusted } \\
\mathrm{R} \\
\text { Square }\end{array}$ & $\begin{array}{l}\text { Std. Error of the } \\
\text { Estimate }\end{array}$ \\
\hline 1 & $.989^{\mathrm{a}}$ & 0.977 & 0.97 & 66228459045.603 \\
\hline
\end{tabular}

Predictors: (Constant), Advertising Tax Receipts

Dependent Variant: Original Income Area

Source: SPSS Version 20.0

The coefficient of determination obtained is 0.977 or $97.7 \%$. This figure is obtained from the calculation of $0.9892=$ 0.977 and the remaining $2.3 \%$ is influenced by other factors not examined in this study.

\section{T test}

The t test basically shows how far the individual independent variables influence the variation of the dependent variable.
To test the validity of each question item, the scores for each question were correlated with the total score. By obtaining the validity index for each item, it can be seen which items do not meet the requirements in terms of their validity. The minimum requirement to fulfill the requirements is $r=0.3$ so that if the correlation between the items and the total score is less than 0.3 then the instrument is invalid (Sugiyono: 116). The results of the $t$ test are as follows:

\begin{tabular}{lllll}
\multicolumn{5}{c}{$\begin{array}{c}\text { Table 6. T test } \\
\text { Coeficients }\end{array}$} \\
\hline Model & $\begin{array}{l}\text { Unstandardized } \\
\text { Coefficients } \\
\text { B }\end{array}$ & $\begin{array}{l}\text { Standardized } \\
\text { Coefficients } \\
\text { Std. error }\end{array}$ & Beta & Sig \\
& - & 1434475974 & & \\
& 9.40147461596 .28 & & & \\
& 9 & -6554 & 0.007 \\
$($ Constant $)$ & 18.045 & 55.974 & & \\
$1 \begin{array}{l}\text { Penerimaan } \\
\text { Pajak } \\
\text { Restoran }\end{array}$ & 1.589 & 11.356 & 0.001 \\
\hline
\end{tabular}


The t test statistic is intended to test the significance of the correlation coefficient with the following provisions: If the probability value $<0.05$ then $\mathrm{Ho}$ is rejected and the test is significant. If the probability value $>0.05$ then $\mathrm{Ho}$ is accepted, the test is not significant.

From the results of data processing shown, the t count is obtained 11.356. The calculated $t$ value is then compared with the t table value. Because t count $>$ when compared with $t$ table, it can be concluded that $\mathrm{Ho}$ is rejected, there is an effect of variable $X$ on $Y$ or in this case there is an effect of billboard tax collection on PAD in Bandung City.

\section{Discussion}

Results of the Verification Discussion Analysis of the effectiveness of the Advertising Tax Collection Against PAD in Bandung

The collection of advertisement tax in the city of Bandung must obtain permission from various parties such as the Parks and Cemeteries Office, the Spatial Planning and Citakarya Office, and the Bandung City Highways. Advertisement Tax is one of the potential supporting sectors for Regional Original Income. In this study the authors examined the contribution of the billboard tax to the Regional Original Income (PAD) of the city of Bandung from 2013 to 2017 , advertisement organizers were individuals or legal entities that held billboards both for and on other dependent parties. The potential subjects of Bandung's advertisement tax are as follows:

\section{Taxpayer}

Taxpayers are individuals or entities who, according to the provisions of the regional tax laws and regulations, make payments due, including certain tax collectors or withholders.

\section{Place for placing advertisement tax}

The place for the installation of billboards is determined based on the following areas: Free area, is an area where advertising activities are not allowed at all, namely government locations, education locations, places of worship, hospitals, military locations, housing and settlement locations, city parks, and areas. other free, based on technical and aesthetic aspects, it does not allow the installation of billboards, the determination of which is further regulated by the Mayor. Selective area, is an area that is allowed to hold activities and selected advertisement points which include historical locations, conservation and preservation locations, other locations considered and determined by the mayor based on the recommendation of the technical team. The results obtained from the comparison of tcount with ttable are tcount $<$ ttable $(-3182<-0.385<3.182)$ so that at a $5 \%$ error level $\mathrm{Ho}$ is accepted and $\mathrm{Ha}$ is accepted, which means the Advertising Tax Contribution variable has no significant effect on Regional Original Income. The advertisement tax is a tax on the implementation of advertisements consisting of tools or objects, direct actions or through the media which according to their patterns and forms have commercial purposes, are used to recommend, praise and introduce people, services and goods in order to attract public attention, and placed in a public place, unless this is done by the government (Nirbeta, 2014). The results of this study support Tilaar's (2013) research which shows that the advertisement tax does not have a significant effect on local revenue. This is due to the fact that the advertisement tax has not yet contributed significantly to the local tax, the advertisement tax contribution is 0.522 . Results of the Verification Discussion on the Contribution of Bill of Advertising Tax Collection on PAD Contribution is calculated by comparing the amount of local tax realization to PAD. Based on Law Number 33 of 2004 concerning Financial Balance between the Central Government and Regional Governments, it is explained that the original regional income, where the sources of local revenue consist of local taxes, regional levies, the results of separated regional wealth management and other original revenues. legal area. Original Regional Revenue aims to 
provide flexibility to regions in obtaining funding in the implementation of Regional Autonomy as a manifestation of Decentralization. The advertisement tax revenue and Regional Original Income (PAD) of Bandung City in Table 5 shows that from 2013 to 2017 it has always increased. Likewise, the contribution that has been fluctuating. The factors that influence local tax revenue from the advertisement tax sector are the rearrangement of road-owned space (green lane) carried out by the Bandung City Government which resulted in decreased billboard tax revenue in 2010. The rearrangement of the road's property is aimed at reducing billboards. billboards that do not have a license or billboards that have expired tax. The following are the results of the hypothesis of the effect of the effectiveness and contribution of advertisement tax collection on PAD where the results obtained from the comparison of $t$ count to $t$ table are $t$ count $<$ table $(-3182<-0,385<3,182)$ so that at an error level of $5 \% \mathrm{Ho}$ is accepted and $\mathrm{Ha}$ is accepted which means the variable The advertisement tax contribution does not have a significant effect on local revenue.Hasil Diskusi Verifikatif Analisis Efektivitas dan Kontribusi Pemungutan Pajak Reklame Terhadap PAD Kota Bandung From the results of the SPSS output that has been presented, it is known that the analysis of the effectiveness and contribution of billboard tax collection on PAD does not have a significant effect on PAD. This is supported by the results of the coefficient of determination test where the results of the number $\mathrm{R}$ Square (the correlation number squared) or 0.52 . This figure is a coefficient of determination equal to $52.2 \%$, which means that local revenue (Y) can be affected by the Effectiveness (X1) and the Advertising Tax Collection Contribution (X2) of $52.2 \%$, while the remaining $47.8 \%$ is the influence of other variables not examined.

\section{CONCLUSION}

From the results of problem identification regarding the Effectiveness Analysis and Contribution of Advertising Tax Collection on Local Revenue in Bandung City, it can be concluded that to answer the problem identification of this study are as follows: Advertising Tax Receipts have a positive effect. It can be seen in the test results of the correlation coefficient, the value of which is 0.989 which shows that the advertisement tax collection has a positive relationship and has a very strong relationship with Regional Original Income. Local Own Revenue has a positive influence and a strong relationship with advertisement tax collection. based on the results of the correlation coefficient with the resulting value 1,000 Regional Original Income has a significant positive relationship with advertisement tax. Advertisement tax collection and PAD have a positive effect with the resulting value of 0.977 or $97.7 \%$ and the rest is influenced by other factors not examined in this study.

\section{REFERENCES}

Febriansyah. (2015). Pengaruh PAD, Dana Alokasi Umum dan Alokasi Khusus Terhadap Kinerja Keuangan Pemda. Jakarta.: PT. Raja Persada.

Fidel, (2010). Konsep Dasar Perpajakan Sampai Aplikasi. Jakarta: PT. Rajawali Grafindo Persada.

Halim, Abdul \& Syukriy Abdullah. 2012. Pengaruh Dana Alokasi Umum dan Pendapatan Asli Daerah Terhadap Belanja Pemda.Jurnal Ekonomi STEI No.2/TahunXIII/25.

Khasanah, Septiyani N. 2014. Sistem Administrasi Yogyakarta: PT. Raja Grafindo.

Mardiasmo. 2013. "Perpajakan". Edisi Revisi. Yogyakarta: Penerbit Andi.

Primadona, Almanda. (2013). Pengelolaan Dana Keuangan Daerah. Jakarta: Alfabeta.

Rustian Kamaludin. 2012, "Peran Dan Pemberdayaan Bumd Dalam Rangka Peningkatan 
Perekonomormian Daerah"

Makalah Disajikan Pada Saat

Rapat Koordinasi Bumd Di

Depdagri.

Sari, Diana. 2013.Konsep Dasar Perpajakan. Bandung: PT Refika Aditama.

Siahaan P, Marihot. 2010. Pajak Daerah dan Restribusi Daerah. Jakarta: PT. Raja Grafindo Persada.

Sugiyono. 2015. Metodologi Penelitian Kuantitatif, Kualitatif Dan $R \& D$. Bandung: ALFABETA.

Syamsuddin, Lukman. 2015. "Perpajakan". Jakarta: Raja Grafindo Persada.

Widyaningsih, Aristanti. 2013. Hukum Pajak dan Perpaja kab. Bandung: Alfabeta.
Undang-Undang Nomor 33 Tahun 2004 Tentang Perimbangan Keuangan Antara Pemerintah Pusat dan Pemerintah Daerah

Undang-Undang Republik Indonesia Nomor 28 Tahun 2009 tentang Pajak Daerah dan Retribusi Daerah. 2011. Jakarta Selatan: Visi Media.

Undang-Undang RI Nomor 32 Tahun 2004 Tentang Pemerintahan Daerah. Watini, S. 2010. Jurnal : Pengaruh Pemungutan Pajak Reklame terhadap Penerimaan Pajak Daerah Kota Bandung, Bandung, Universitas Kristen Maranatha. 